\title{
Comparison of the Effects of Ketamine and Memantine on Prolactin and Cortisol Release in Men: A Randomized, Double-blind, Placebo-controlled Trial
}

Nicole Hergovich, M.D., Ernst Singer, M.D., Ernst Agneter, M.D., Hans Georg Eichler, M.D., Ursula Graselli, R.N., Christian Simhandl, M.D., and Bernd Jilma, M.D.

$N$-methyl D-aspartate (NMDA)-antagonists decrease neurotoxicity by inhibiting $\mathrm{Ca}^{2+}$ influx which is of interest for the treatment of acute cerebrovascular insults and chronic neurodegenerative disorders. Currently, there is no surrogate marker for quantification of NMDA-receptormediated drug effects, which hampers dose-finding clinical studies. As prolactin and cortisol liberation is in part influenced through NMDA-receptors we investigated whether the elevation of prolactin or cortisol plasma levels is a class effect of NMDA-antagonists and might be an appropriate marker for studying NMDA-antagonistic potency. Fifteen healthy male volunteers participated in this placebo-controlled, randomized, three-way crossover trial. Ketamine $(0.5 \mathrm{mg} / \mathrm{kg})$, memantine $(0.16 \mathrm{mg} / \mathrm{kg}$; i.e., a well tollerated standard dose) or placebo were infused over 60 min. Ketamine increased serum prolactin and cortisol levels $(p<0.001)$, whereas memantine and placebo did not affect hormone levels. Further studies are needed to define whether higher doses of memantine or other NMDA antagonists can induce hormone release.

[Neuropsychopharmacology 24:590-593, 2001] (C) 2001 American College of Neuropsychopharmacology. Published by Elsevier Science Inc. All rights reserved
KEY WORDS: NMDA; Memantine; Ketamine; Cortisol; Prolactin; Drug development

Overstimulation of the N-methyl-D-aspartate (NMDA) receptor, a subtype of glutamate receptors, leads to excessive entry of calcium ions into neurons causing subsequent cell damage. This mechanism of neurotoxicity

From the Department of Clinical Pharmacology, Vienna University School of Medicine, Vienna, Austria (NH, HGE, UG, BJ); the Institute of Pharmacology, Vienna University School of Medicine, Vienna, Austria (ES, EA); and the Department of Psychiatry, Vienna University School of Medicine, Vienna, Austria (CS).

Address correspondence to: Bernd Jilma, MD, Department of Clinical Pharmacology, TARGET, Vienna University Hospital School of Medicine, Waehringerguertel 18-20, A-1090 Vienna, Austria. Tel.: +43-1-40400-2981; Fax: +43-1-40400-2998; E-mail: Bernd. Jilma@univie.ac.at

Received January 17, 2000; revised June 14, 2000; accepted August 8, 2000. is associated with acute and chronic neurodegenerative disorders (Danysz and Parsons 1998) and schizophrenia (Abi-Saab et al. 1998), so that NMDA receptors are potential pharmacological targets.

There are currently no biologic markers available to quantify the potency of NMDA antagonists. Yet, NMDA receptors are involved in the physiologic pulsatile regulation of hormone release from the hypothalamo-pituitary-axis (Arslan et al. 1992; Bhat et al. 1995, Jezova et al. 1991). Measurement of prolactin and cortisol levels may thus reveal a drug's possible NMDA receptor antagonistic potency. Additionally, hormone levels would be readily accessible parameters for dose finding studies and for establishing minimally effective concentrations of certain NMDA antagonists.

In this study we investigated whether the rise in prolactin and/or cortisol serum levels could be a class ef- 
fect of NMDA-antagonists. We thus compared the effects of two well known NMDA-antagonists, ketamine and memantine, on prolactin and cortisol release, though they show different interactions with the glycin-binding sites (Danysz and Parsons 1998), different degrees of trapping in the ion channel and differences in their binding affinities and receptor blocking actions (Mealing et al. 1999).

\section{METHODS}

\section{Subjects}

The sample size of 15 subjects was based on a previous study investigating the endocrine effects of ketamine (Krystal et al. 1994). The study protocol and informed consent form were approved by the local Ethics Committee, and all subjects undersigned the nine pages of the informed consent in the presence of a physician and a witness. All subjects underwent a battery of laboratory and physical screening tests as described previously (Jilma et al. 1996). Inclusion criteria were healthy, as defined by the absence of disease, male sex, age 19-35 years, drug free. Subjects had a body mass index of $22.8 \pm$ $0.5 \mathrm{~kg} / \mathrm{m}^{2}$ (mean $\pm \mathrm{SD}$ ). A psychiatric examination (open questions concerning familial and medical history, International Personality Disorders Examination and Structured Clinical Interview for DMS) was performed because NMDA-antagonists can dose-dependently provoke psychotomimetic effects (Krystal et al. 1994, 1999; Newcomer et al. 1999). Any evidence of prior or active psychiatric disorder or family history of such was defined as exclusion criterion.

\section{Study Design}

The study was placebo-controlled, balanced-randomized (by randomization tables), three-way crossover with a wash-out period of at least six days between study-days.

\section{Experimental Procedures and Medications}

Volunteers reported at 07:45, a.m. on each trial day to the study ward. An indwelling catheter (21 gauge) was inserted and after a $1 \mathrm{hr}$ resting-period ketamine (Keta$\operatorname{lar}^{\circledR} 0.5 \mathrm{mg} / \mathrm{kg}$, Parke Davis), memantine (Akatinol Memantine Injektionslösung ${ }^{\circledR} 0.16 \mathrm{mg} / \mathrm{kg}$, Merz \& Co) or placebo (physiologic saline solution) were infused over $60 \mathrm{~min}$. Blood was sampled twice at $10 \mathrm{~min}$. intervals before infusion of any drug and for $2 \mathrm{~h}$ after the start of infusion (Figure 1). Blood pressure was measured at 5 min intervals, a real time ECG was monitored continuously and pulse rate was recorded from a finger pulseoxymeter on a HP-CMS monitor system (Hewlett Packard, Palo Alto, CA).

\section{Methods}

Cortisol and prolactin serum levels were measured by enzyme immunoassay (Enzymun-Test ${ }^{\mathrm{TM}}$ Cortisol and Prolactin, Boehringer Mannheim Immundiagnostica, limit of sensitivity: $27.6 \mathrm{nmol} / \mathrm{L}$ and $1 \mathrm{ng} / \mathrm{mL}$, respectively). Intra-assay coefficients of variation (CV) were $<2 \%$ and inter-assay $\mathrm{CV}$ were $<7 \%$.

\section{Data Analysis}

Treatment effects on hormone levels and cardiovascular parameters are described as means \pm SEM. We used a two-way ANCOVA for analysis of treatment effects (treatment $=$ indepedent factor, subject $=$ covariate, outcome variable $=$ dependent factor in a repeated measures design). A $p$-value of 0.05 was considered significant. F-values are provided for main effects.

\section{RESULTS}

Basal serum cortisol and prolactin levels were not significantly different between periods.

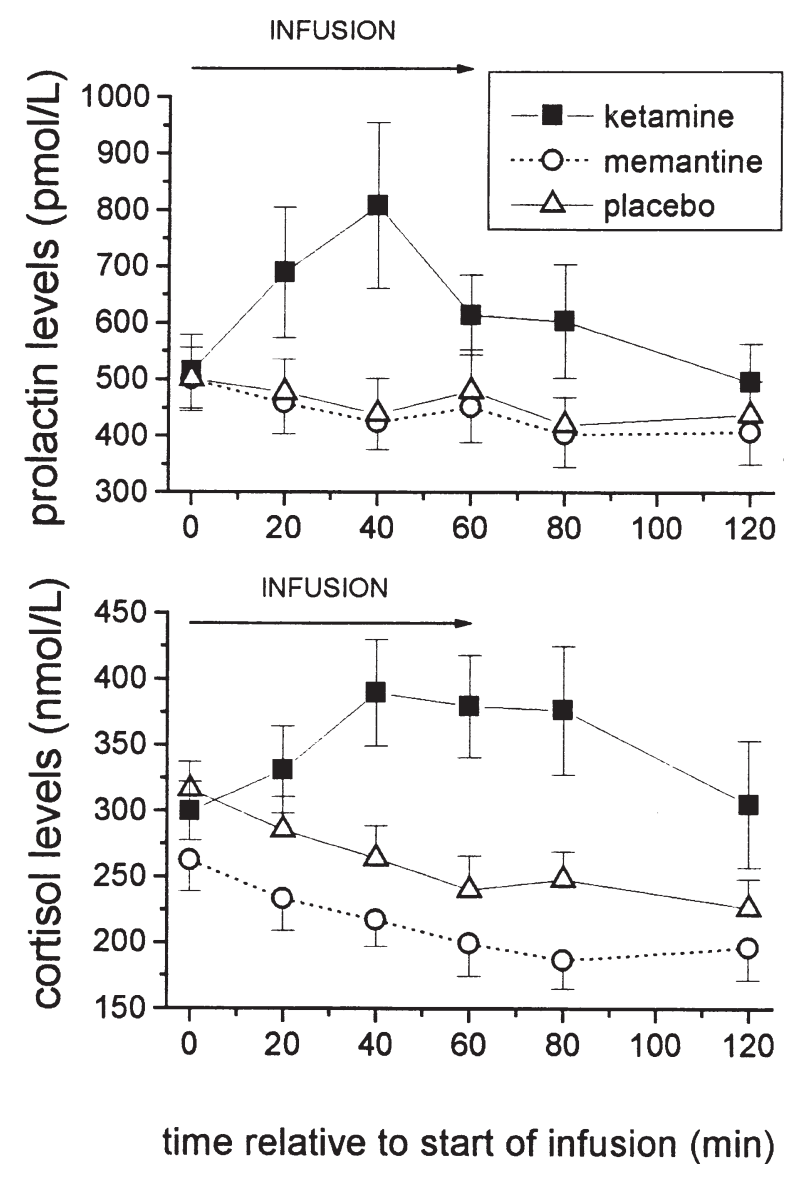

Figure 1. Mean serum prolactin (top layer) and cortisol (bottom layer) levels after ketamine, memantine and placebo infusion (indicated by the arrows). Data is mean \pm SEM $(n=15)$. 


\section{Prolactin}

Prolactin levels steadily declined during placebo and memantine infusion with nadir levels seen at $120 \mathrm{~min}$. In contrast, ketamine increased prolactin serum levels after $40 \mathrm{~min}$ of infusion, which differed significantly from the decrease observed after memantine and placebo infusion $(\mathrm{F}=3.66$, [df $=12], p<.001$; Figure 1$)$

\section{Cortisol}

Cortisol levels steadily declined during placebo and memantine infusion with nadir levels at $80 \mathrm{~min}$. In contrast ketamine increased cortisol serum levels at $60 \mathrm{~min}$ after infusion, which differed significantly from the decrease observed after memantine or placebo infusion $(\mathrm{F}=$ 7.68, [df = 12]; $p<.001$; Figure 1).

\section{Effects on Blood Pressure and Pulse Rate}

Ketamine, but not placebo or memantine, infusion increased systolic $(\mathrm{F}=5.56)$ and diastolic blood pressure $(\mathrm{F}=2.16)$ and heart rate $(\mathrm{F}=3.00)$ on average by $10-15 \%([\mathrm{df}=16]$ and $p<.001$ in all cases; Figure 2$)$.

\section{Drug-tolerability}

The ketamine infusion was discontinued in two subjects after minor adverse events. Sweating, dizziness, and paresthesia in the finger tips and around the mouth were reported; all data were included in an intention to treat analysis and the last observation was carried forward. No adverse events were reported during memantine infusion.

\section{DISCUSSION}

Ketamine increased prolactin and cortisol levels, which is in good agreement with data obtained by Krystal et al. (1994). In contrast, no significant differences were observed between the memantine and placebo period ( $p<.827)$. The fall in plasma prolactin and cortisol levels in the memantine and placebo groups represents well-known circadian changes (Miyatake et al. 1980).

This study demonstrates that tolerable doses of two non-competitive open ion channel blocking NMDAantagonists can provoke different hormonal release reactions in healthy volunteers (Figure 1).

First, it is a clear limitation of our study that we examined only one well-tolerated dose of memantine $(0.16 \mathrm{mg} / \mathrm{kg})$, which is a standard dose according to the
Austrian Summary of Products Characteristics, but may be much too low to affect prolactin or cortisol concentrations, because there is evidence that high-dose memantine $(20 \mathrm{mg} / \mathrm{kg})$ increases at least cortisol levels in rats (Zhou et al. 1998). Second, it is possible that the release of both hormones is triggered by a sympathomimetic effect of ketamine, because only ketamine affected cardiovascular parameters (Figure 2), and epinephrine and exercise are both well known stimuli for hormone release (Willems et al. 2000; Deuster et al. 2000). Third, memantine and ketamine have different effects on dopamine (Smith et al. 1998; Bregonzio et al. 1998; Puri et al. 1981) release, which controls prolactin release. Finally, ketamine infusion could also release prolactin by a direct effect on prolactin secreting cells (Wickings and Nieschlag 1980).

In conclusion, ketamine, in contrast to low dose memantine $(0.16 \mathrm{mg} / \mathrm{kg})$, elevates serum prolactin and cortisol levels in healthy men.

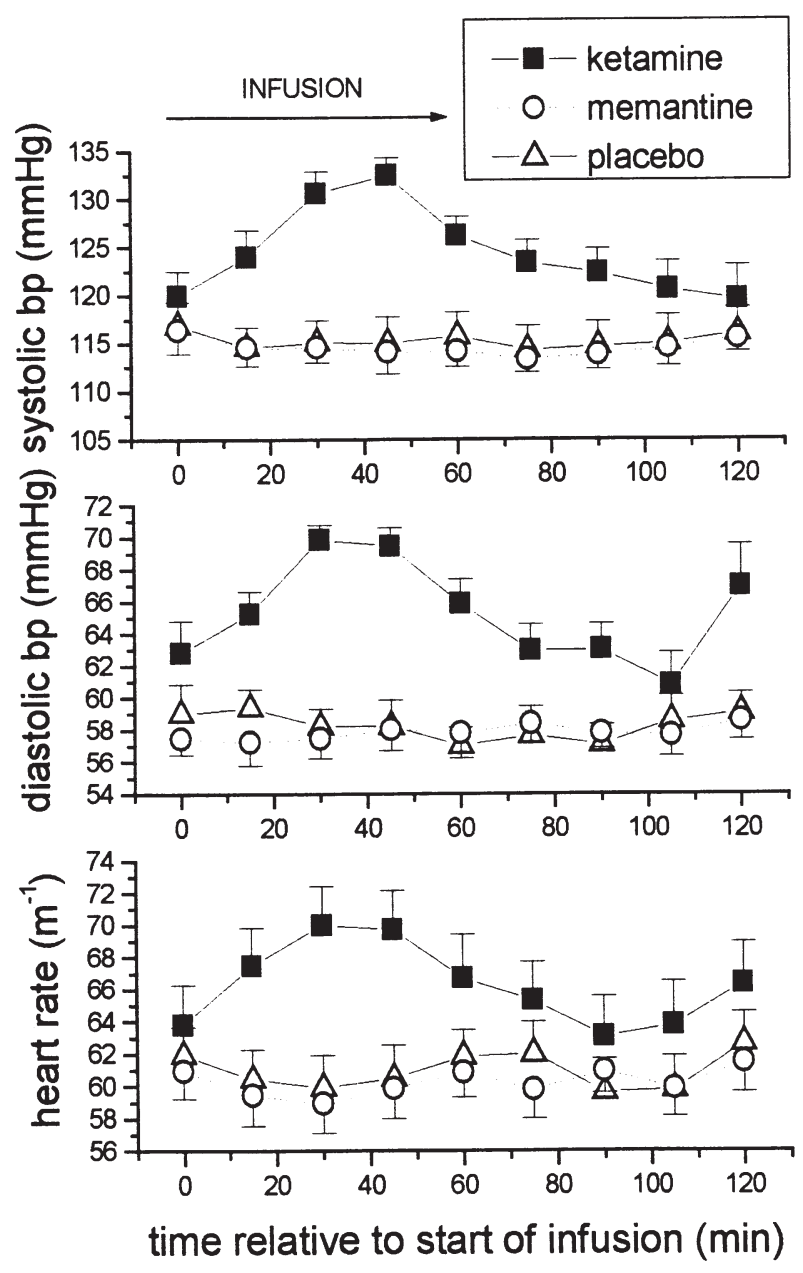

Figure 2. Mean values of systolic and diastolic blood pressure $(\mathrm{mmHg})$ and heart rate $\left(\mathrm{m}^{-1}\right)$ after ketamine, memantine and placebo infusion (indicated by the arrow). Data is mean $\pm \operatorname{SEM}(n=15)$. 


\section{REFERENCES}

Abi-Saab WM, D'Souza DC, Moghaddam B, Krystal JH (1998): The NMDA antagonist model for schizophrenia: promise and pitfalls. Pharmacopsychiatry 31(Suppl 2)104-109

Arslan M, Pohl CR, Smith MS, Plant TM (1992): Studies of the role of the N-methyl-D-aspartate (NMDA) receptor in the hypothalamic control of prolactin secretion. Life Sci 50:295-300

Bhat GK, Mahesh VB, Chu ZW, Chorich LP, Zamorano PL, Brann DW (1995): Localization of the N-methylD-aspartate R1 receptor subunit in specific anterior pituitary hormone cell types of the female rat. Neuroendocrinology 62:178-186

Bregonzio C, Navarro CE, Donoso AO (1998): NMDA receptor antagonists block stress-induced prolactin release in female rats at estrus. Eur J Pharmacol 350:259-265

Danysz W, Parsons CG (1998): Glycine and N-methylD-aspartate receptors: Physiological significance and possible therapeutic applications. Pharmacologic Rev 50:597-664

Deuster PA, Petrides JS, Singh A, Chrousos GP, Poth M (2000): Endocrine response to high-intensity exercise: dose-dependent effects of dexamethasone. J Clin Endocrinol Metab 85:1066-1073

Jezova D, Oliver C, Jurcovicova J (1991): Stimulation of adrenocorticotropin but not prolactin and catecholamine release by $\mathrm{N}$-methyl-aspartic acid. Neuroendocrinology 54:488-492

Jilma B, Eichler HG, Vondrovec B, Breiteneder H, Kyrle PA, Kitzweger E, Kapiotis S, Speiser W. (1996): Effects of desmopressin on circulating P-selectin. Br J Haematol 93:432-436

Krystal JH, Karper LP, Seibyl J, Freeman GK, Delaney R, Bremner JD, et al. (1994): Subanesthetic effects of the noncompetitive NMDA antagonist, ketamine, in humans. Psychotomimetic, perceptual, cognitive, and neuroendocrine responses. Arch Gen Psychiatry 51:199-214

Krystal JH, D'Souza DC, Karper LP, Bennett A, AbiDargham A, Abi-Saab D, Cassello K, Bowers MB Jr, Vegso S, Heninger GR, Charney DS (1999): Interactive effects of subanesthetic ketamine and haloperidol in healthy humans. Psychopharmacology (Berl) 145:193204

Mealing GA, Lanthorn TH, Murray CL, Small DL, Morley P (1999): Differences in degree of trapping of low-affinity uncompetitive N-methyl-D-aspartic acid receptor antagonists with similar kinetics of block. J Pharmacol Exp Ther 288(1):204-210

Miyatake A, Morimoto Y, Oishi T, Hanasaki N, Sugita Y, Iijima S, et al. (1980): Circadian rhythm of serum testosterone and its relation to sleep: comparison with the variation in serum luteinizing hormone, prolactin and cortisol in normal men. J Clin Endocrinol Metab 51:1365-1371

Newcomer JW, Farber NB, Jevtovic-Todorovic V, Selke G, Melson AK, Hershey T, Craft S, Olney JW (1999): Ketamine-induced NMDA receptor hypofunction as a model of memory impairment and psychosis. Neuropsychopharmacology 20:106-118

Puri CP, Puri V, Anand Kumar TC (1981): Serum levels of testosterone, cortisol, prolactin and bioactive luteinizing hormone in adult male rhesus monkeys following cage-restraint or anaesthetizing with ketamine hydrochloride. Acta Endocrinol Copenh 97:118-124

Smith GS, Schloesser R, Brodie JD, Dewey SL, Vitkun SA, Simkowitz P, Hurley A, Coper T, Volkow ND, Cancro R (1998): Glutamate modulation of dopamine measured in vivo with positron emission tomography (PET) and 11C-raclopride in normal human subjects. Neuropsychopharmacology 18:18-25

Wickings EJ, Nieschlag E (1980): Pituitary response to LRH and TRH stimulation and peripheral steroid hormones in conscious and anesthetized adult male rhesus monkeys (Macaca mulatta). Acta Endocrinol Copenh 93:287-293

Willems E, Knigge U, Jorgensen H, Kjaer A, Warberg J (2000): Effect of blockade of postsynaptic H1 or H2 receptors or activation of presynaptic $\mathrm{H} 3$ receptors on catecholamine-induced stimulation of ACTH and prolactin secretion. Eur J Endocrinol 142:637-641

Zhou Y, Yuferov VP, Spangler R, Maggos CE, Ho A, Kreek MJ (1998): Effects of memantine alone and with acute 'binge' cocaine on hypothalamic-pituitary-adrenal activity in the rat. Eur J Pharmacol 352:65-71 
